\title{
MARITAL RAPE: A TALE OF TWO LEGAL SYSTEMS
}

\author{
Oyebanke Yebisi \\ LLB LLM \\ Victoria Balogun \\ LLB LLM \\ Lecturer, School of Law \\ University of KwaZulu-Natal, Pietermaritzburg
}

\section{SUMMARY}

Marital rape is a form of sexual violence, which is often downplayed due to the common law position that a man cannot rape his wife. While certain jurisdictions have enacted laws criminalising it, other jurisdictions have yet to criminalise it. This paper focuses on the criminal aspects of marital rape and examines the laws regarding marital rape in South Africa and the general rape provisions in Nigeria. While marital rape is punishable under South African criminal law, it is not in Nigeria In this paper, the provisions of the South African Criminal Law (Sexual Offences and Other Related Matters) Act of 2007, the Criminal Code Act, and the Penal Code Act Nigeria in relation to rape and marital rape - are analysed. This paper also discusses the South African Sexual Offences Court, sentencing for rape in the selected countries, and relevant case law. It concludes that South Africa (SA) has a generally good framework with respect to rape and marital rape, but the country should work more on the strict application of the laws in place. It also suggests that Nigeria should establish a sexual offences court using the South African model and should amend the Criminal Law to expressly criminalise marital rape.

\section{$1 \quad$ INTRODUCTION}

Sexual offences are comprised of various offences of a sexual nature, including sexual abuse as a form of violence against women. Women experience sexual violence on a regular basis, leaving them with various forms of trauma and injury. ${ }^{1}$ The World Health Organisation ${ }^{2}$ defines sexual violence to include rape within marriage or dating relationships; rape by strangers; unwanted sexual advances or sexual harassment, including demanding sex in return for favours; sexual abuse of children; forced marriage or cohabitation, including the marriage of children; and violent acts against the sexual integrity of women, including female genital mutilation and

\footnotetext{
$1 \quad$ United Nations Development Fund for Women "Ending Violence against Women and Girls Literature Review and Annotated Bibliography" August 2010 http://www.unicef.org/ pacificislands /evaw.pdf (accessed 2016-02-24).

2 Hereinafter "the WHO".
} 
virginity testing, and forced prostitution and trafficking of women for sexual exploitation. ${ }^{3}$ Marital rape, otherwise called spousal rape or rape in marriage, is conceived as any unwanted sexual intercourse or penetration ${ }^{4}$ obtained by force - or when the wife is unable to consent. ${ }^{5}$ Though rape in marriage impacts negatively on the physical and psychological health of women, ${ }^{6}$ the universal response to the heinous act is not uniform.

In a survey conducted in South Africa, it was found that even though sexual violence largely goes unreported, the South African Police Service (SAPS) reported that cases of sexual violence rose from 66079 in 2003 to 71500 in 2009. ${ }^{8}$ In a 2014 report, the Institute for Security Studies found that rape and other forms of sexual violence are under-reported due to certain barriers, especially the fear of legal processes, including experiencing rudeness and poor treatment by the police, and fear of having to relive the trauma in court and during the investigation. ${ }^{9}$ In a direct contrast to the 2009 statistics on sexual abuse, according to Africa Check, South Africa recorded 51895 sexual offence cases with an average of 142.22 cases per day, and a total of 42596 cases of rape were recorded during this same period. Although this is slightly higher than the 2009 record, there seems to have been a slight drop from the 2014/15 record of 99000 which had an average of 94.3 abuse cases reported per day during that period. ${ }^{10}$ There seem to be some inconsistencies; under-reporting is highly blamed for the fluctuating record. In a study at a tertiary health facility in a rural community in northwest Nigeria, it was found that most sexual violence cases reported are attempted rape or rape in adults and children. ${ }^{11}$ According to Ola et al, many cases of marital rape go unreported in Nigeria because the burden of proof required to sustain a charge of rape in Nigeria is so high that victims rarely

3 WHO "World Report on Violence and Health, 2002 http://apps.who.int/iris/bitstream/10665/ 42495/1/9241545615_eng.pdf (accessed 2015-09-25) 149-150.

4 Vaginal, anal, or oral.

5 Bergen "Marital Rape" 199910 National Electronic Network on Violence against Women 1 1.

6 Norton The Role of Law in Confronting Marital Rape (Unpublished LLM dissertation, University of Ghana, Legon 2009) 10.

7 Countries such as The Gambia, Ghana, Zimbabwe and Australia have all criminalised marital rape. However, the act is not criminalised in countries like Zambia, Nigeria, Botswana, Bangladesh and India. OMICS International "Marital Rape" undated http://research.omicsgroup.org/index.php/Marital_rape\#Countries_where_spousal_rape_is_ a_criminal_offence (accessed 2016-07-27).

8 Sigsworth "An Overview of Sexual Violence in South Africa" November 2009 https://www.issafrica.org/crimehub/uploads/sexualviolenceAnyone_can_be_a_rapist.pdf (accessed 2015-09-25)

9 Vetten "Rape and other forms of Sexual Violence in South Africa" November 2014 Institute for Security Studies Policy Brief https://www.issafrica.org/uploads/PolBrief72.pdf (accessed 2015-09-25) 72.

10 Africa Check "FACTSHEET: South Africa's 2015/16 crime statistics" https://africacheck.org/ factsheets/factsheet-south-africas-201516-crime-statistics (accessed on 2017-06-26).

11 Ashimi, Amole and Ugwa "Reported Sexual Violence among Women and Children seen at the Gynaecological Emergency Unit of a Rural Tertiary Health Facility, Northwest Nigeria" 20155 Annals of Medical and Health Sciences Research 2626. 
succeed in court. ${ }^{12}$ This is so given regard to the rules of evidence imposed by the courts. ${ }^{13}$

Marital rape has two dimensions - a criminal and a social aspect. The criminal aspect deals with the laws prohibiting marital rape and rape in general, while the social aspect entails the health, gender, and societal responses to marital rape. Focusing on the criminal aspect of marital rape, this paper discusses and analyses the laws pertaining to marital rape in South Africa and Nigeria, particularly focussing on the Criminal Law (Sexual Offences and Other Related Matters) Act of 2007 (of SA), the Criminal Code Act and the Penal Code Act (of Nigeria), relevant cases of rape, sentencing for rape, and the establishment of the Sexual Offences Court in South Africa. These countries have been selected because of the role they play in their sub-regional communities; ${ }^{14}$ the size of the economy of the respective countries and the cultural diversity in their large populace. It is important to note that although SA has an existing legal framework, expressly prohibiting marital rape, its Nigerian counterpart does not. Therefore, for the purpose of this paper, the section on Nigeria will focus on the Criminal Law provisions relating to rape in Nigeria.

\section{MARITAL RAPE AND THE ROLE OF LAW}

Historically, in patriarchal societies, a married woman has no control over her body and sexuality, as her husband determines when to engage in sexual intercourse - which means, a married woman's power to negotiate sex is at the discretion of her spouse. ${ }^{15}$ The notion of rape in marriage was not recognised. This view is also reinforced generally by religious ${ }^{16}$ and cultural ${ }^{17}$ notions that a wife must submit to her husband's will. From early

12 Ola and Ajayi "Values Clarifications in Marital Rape: A Nigerian Situation" 2013 9(35) European Scientific Journal 291294.

13 See Sambo $v$ The State [1993] 6 NWLR (Pt 300) 399; Akpanefe $v$ The State [1969] 1 All NLR 420, where the court held that before the prosecution can secure a conviction of rape, there is a need for corroboration of the evidence of the victim. However, in Iko $v$ The State [2001] 14 NWLR (Pt 732) 221, it was stated that the proper direction is that it is not safe to convict on the evidence of the victim alone, except where the court is satisfied with the guilt of the accused person, though the court still maintained that corroboration is important.

14 That is, Nigeria in the Economic Community of West African States (hereinafter "the ECOWAS") and South Africa in Southern African Development Community (hereinafter "SADC").

15 Langa "Notions of Sex, Masculinity and Manhood in African Cultures" 20143 BUWA 2020 23 http://www.osisa.org/sites/default/files/notions_of_sex_masculinity_and_manhood_in_ african_cultures.pdf (accessed 2016-08-01).

16 According to Ephesians 5 verses 22-24 (KJV),"Wives submit yourselves unto your own husbands as unto the Lord for the husband is the head of the wife, even as Christ is the head of the church and He is the saviour of the body. Therefore as the church is the subject unto Christ, so let the wives be to their husbands in everything." It would seem that the word "everything" has been misinterpreted to perpetuate sexual violence against women - such as marital rape.

17 Sambe, Avanger, and Agba "The Effects of High Bride-Price on Marital Stability" 2013 17(5) Journal of Humanities and Social Sciences 65 66. See, also, Muthegheki, Crispus and Abrahams "An Exploratory Study of Bride-Price and Domestic Violence in Bundibugyo District, Uganda" April 2012 Centre for Human Rights Advancement http://www.mrc. ac.za/gender/Bridepricedomestic violence.pdf (accessed 2016-07-27); Nwoke "Bride-Price 
times, the law has exempted the husband from liability for rape where he had sexual intercourse with his wife against her will, on the fiction that from the date of the marriage, she gives irrevocable consent to her husband to have sexual intercourse with him - as and when he desires. ${ }^{18}$ This position was affirmed by Sir Matthew Hale thus: "But the husband cannot be guilty of a rape committed by himself upon his lawful wife, for by their mutual matrimonial consent and contract the wife hath given up herself in this kind unto her husband which she cannot retract." ${ }^{\prime 19}$ This statement supports the previously accepted doctrine that a man cannot rape his wife, which is still to some extent upheld by countries that have not criminalised marital rape. In many Commonwealth countries, the common law reform on marital rape is conducted in a piecemeal manner that still gives recognition to the practice, but some courts have gradually rejected the act as being unacceptable. In countries like the UK and The Gambia, the courts, social circumstances, and attitudes of the people have changed over the years - to bring about the total rejection of the doctrine in societies, which once fuelled the practice. ${ }^{20}$

Rape within marriage constitutes violence against women, ${ }^{21}$ although many proponents of the practice are sometimes reluctant to accept this classification. The erroneous belief justifying rape in marriage as an act of aggression is based on a misconception that the institution of marriage itself is originally founded on male supremacy over a woman's body, which gives a man the right to assault his wife (spouse) as a corrective practice. Women are often encouraged by family members to tolerate the aggression and to refrain from involving outsiders or to take any legal steps to prevent or stop the abuse. In an effort to shed some light on the problem of marital rape in Asia, Hassan, having studied the plight of women in Pakistan states:

"Unwanted sexual attacks are seen as part of the institutions of marriage that have to be endured and the concept of exercising sexual choice does not exist. Marital rape is not considered to be a crime in Pakistan because women are seen as the property of their husbands, which they can use as they

and Implications for Women's Rights in Nigeria: Psychological Perspective" 2009 17(1) Gender and Behaviour Journal 20782081.

18 It would seem like since time immemorial, married women have always been doomed, looking at $R \vee$ Gumede 1946 (1) PH H68 (N) for instance, Hathorn JP, stated that among others, "A husband cannot be found guilty of raping his wife, by reason of her consent in marriage". Decisions like this must have given married men the legal platform to rape women without deterrence.

19 Hale History of the Pleas of the Crown In Slapper and Kelly The English Legal System 9ed (1993) 209.

20 The Times "Wave of Prosecutions will Follow" 24 October 1991 The Times http://www.womenagainstrape.net/success/marital-rape-ruled-illegal-law-lords (accessed 2016-08-08). In that decision reported by the Sunday Times, Lord Keith, with Lords Brandon, Griffiths, Ackner and Lowry unanimously did away with a 250-year-old notion that women agree to sexual intercourse on marriage and cannot revoke their consent. See Painter Wife Rape in the United Kingdom Paper presented at the American Society of Criminology, 50th Anniversary Meeting, San Francisco (20-23 November 1991).

21 UN Committee on the Elimination of Discrimination against Women, General Recommendation No. 19: Violence against Women, adopted at the eleventh session, 1992. According to the Committee, every form of violence against women should be prohibited at all costs by the state, including rape, family violence, and discrimination in all its forms. See par $6,11,15,16,23$ and $24(a)$ and (k). 
please. Consequently, a man's forcing himself upon his wife is seen as part of the marital relation.

A critical look at the above quote seems to highlight men's dominance over women's interests in a marriage and marital affairs are private matters outside the compass of the law - which should not be meddled with. However, given the primary need to protect, promote, and fulfil women's rights against violence in a democratic state, it is therefore undoubtedly important for the state to intervene and to ensure that the human rights law prevails. In an effort to curtail how the masculine mentality is dehumanising women in Africa in the name of culture and tradition, the law should be embraced and used to strike back in the middle of the unacceptable pervasive ideology of violent patriarchal practices like marital rape. The development of laws prohibiting marital rape, as implemented in South Africa in 1993, Zimbabwe in 2001, and Lesotho in 2003 shows that Criminal Law plays a role in eradicating the marital rape problems in these countries. ${ }^{23}$ It follows therefore, that implementation is necessary to complement the laws addressing marital rape issues as illustrated in the next sections of this paper.

\section{SOUTH AFRICA}

\section{Criminal Law (Sexual Offences and Other Related Matters) Act of 2007}

The Criminal Law (Sexual Offences and Related Matters) Amendment Act (SORMA) was born out of a review by the South African Law Reform Commission $^{24}$ of cases of sexual offences like sexual assault, as directed by the Minister of Justice and Constitutional Development. ${ }^{25}$ The offence of rape is clearly defined in section 3 of the SORMA, which provides that "any person ('A') who unlawfully and intentionally commits an act of sexual penetration with a complainant ('B'), without the consent of $B$, is guilty of the offence of rape." By virtue of section 1, sexual penetration includes:

"any act which causes penetration to any extent whatsoever by the genital organs of one person into or beyond the genital organs, anus, or mouth of another person; any other part of the body of one person or, any object, including any part of the body of an animal, into or beyond the genital organs or anus of another person; or the genital organs of an animal, into or beyond the mouth of another person."

22 Hassan Heaven Becomes Hell: A Study of Domestic Violence in Pakistan (1995) 31. Hassan concedes that the issue of marital rape and violence against women, including domestic violence, knows no boundaries and therefore is found all over the world, including sub-Saharan Africa.

23 RSA passed the Prevention of Family Violence Act No. 131 in 1993; Lesotho passed its Sexual Offences Act No. 3 in 2003 and Zimbabwe passed its Sexual Offences Act No. 8 in 2001. In essence, these statutes prohibit every form of violence within the family including Marital Rape.

24 Hereinafter "the SALRC".

25 Fuller "Bureaucracy versus Democratisation: The Promulgation of the Criminal Law (Sexual Offences and Related Matters) Amendment Bill" (undated) http://www.csvr.org.za/wits /papers/papfull.pdf (accessed 2016-02-16). 
This definition incorporates a variety of acts of sexual penetration, including penetration with various objects, as opposed to the common law definition that covers only the insertion of the penis of a man into the vagina of a woman. ${ }^{26}$ Section 1(2) defines consent as "voluntary or uncoerced agreement". Circumstances in respect of which a person "does not voluntarily or without coercion agree to an act of sexual penetration", include the use of force or intimidation, a threat of harm, abuse of power or authority, false pretences, or where the complainant is incapable of appreciating the nature of the sexual act (that is, where at the time of the commission of the sexual act, the complainant is asleep, unconscious, in an altered state of consciousness, a child below the age of 12 years or a mentally disabled person). ${ }^{27}$

At this point, a question, which readily comes to mind, is whether marital rape is a form of rape under the SORMA. In answering this question, it is instructive to note that the common-law position that a husband cannot be found guilty of raping his wife was abolished by section 5 of the Prevention of Family Violence Act of 1993, which provides that a husband may be convicted of raping his wife. ${ }^{28}$ This section has, however, been repealed by the combined reading of sections 3 and 56(1) of the SORMA which is to the effect that whenever an accused person is charged with the offence of rape, it is not a valid defence to contend that a marital or other relationship exists or existed between him or her and the complainant. In effect, in respect of a rape charge, the fact of a subsisting marriage or indeed any other relationship cannot be used as a defence. The contributions made by the Prevention of Family Violence Act, however, cannot be overstated given the scourge of violence South African women, especially; African women were subjected to behind closed doors.

It is trite that before an accused person can be convicted of a crime, the actus reus ${ }^{29}$ and the mens rea ${ }^{30}$ must be proved. ${ }^{31}$ Accordingly, apart from proving that the accused person committed the physical act of rape, he must also have a guilty mind. In $R \vee K^{32}$ the court stated, "the accused must intend unlawfully to sexually penetrate the complainant, knowing or at least foreseeing that the complainant has not consented to the act of penetration". ${ }^{33}$ The confusion posed by categorising marital rape as a criminal offence is that, traditionally, women were not expected to initiate sex - meaning, the man must do so and there is a schedule or limitation on how or where he may express his sexual desires. ${ }^{34}$

Burchell Principles of Criminal Law 3ed (2013) 595

S 1(3) of the SORMA.

Burchell Principles of Criminal Law 598.

The physical act of the crime.

Mental intent to commit the crime.

$S$ v Mbatha (AR265/11) [2012] ZAKZPHC 23; 2012 (2) SACR 551 (KZP).

1958 (3) SA 420 (A) 421.

33 Burchell Principles of Criminal Law 609. See, also, Burchell Cases and Materials on Criminal Law 4ed (2016) 859.

34 Kim, Sorsoli, Collins, Zylbergold, Schooler and Tolman "From Sex to Sexuality: Exposing the Heterosexual Script on Primetime Network Television" 2007 J Sex Res. 44(2) 145-157. 
Victims of sexual offences, including rape, who fail to report on time, are also protected by the SORMA. Section 59 prohibits courts from drawing adverse inferences merely from the length of any delay between the alleged commission of such offence and the reporting. This provision is laudable in that some victims of rape may not want to come forward due to the psychological impact of the violation or for fear of being victimised or ostracised but may later change their minds. In addition, with regard to the evaluation of evidence, section 60 prohibits courts from treating the evidence of a complainant with caution due to the nature of the offence. This implies that where the court finds a victim to be a credible witness, the court may not treat the testimony of such a witness with caution simply because the offence in question is a sexual offence. Thus, the need for corroboration of the evidence of the victim has been eliminated. Reddi posits that the abolition of this procedural requirement, that is corroboration in cases of a sexual nature ${ }_{35}$ may result in an increase in the conviction rates of crimes such as rape. ${ }^{35}$

\section{Law Reform and Marital Rape under South African Criminal Law}

Although one may contend that legal responses are insufficient to tackle rape, including marital rape problems in a country, regardless of whether the parties were intimate or not, ${ }^{36}$ South Africa like many other progressive countries, have condemned every form of rape by criminalising it. Sensitisation and strategic advocacy programmes on the conduct that highlights gender gaps fuelling the problem are still needed as such will pave the way for gender tolerance and equality.

Over the years, various cases have been handed down by the courts relating to marital rape incidences, even where the courts have failed to condemn or penalise the act in the strongest manner, marital rape remains crime according to national law.

In Moipolai $v$ The State ${ }^{37}$ the court erred in its findings that the appellant's sentencing must be reduced given that he was the complainant's lover for 7 years and they were expecting their "third" child together. Mogoeng JP, as he then was, stated that:

"the Complainant [Matron] must have come knowing that this was either likely to happen or was going to happen for sure and she was, given the nature of their relationship, willing to take part in the intercourse" inferring that Matron must have been fully aware that she might be raped and yet went to her exboyfriend's place to be raped ... 'this rape should therefore, be treated differently from the rape of one stranger by another between whom consensual intercourse was almost unthinkable."'

\footnotetext{
35 Reddi "Violence against Women" in Hoctor and Schwikkard (eds) The Exemplary Scholar Essays in Honour of John Milton (2007) 71.

$36 \mathrm{~S} 3(\mathrm{aA})$ of the Criminal Law Amendment Act, 2007.

37 (CA 53/2004) [2004] ZANWHC 19 Grant The Exemplary Scholar: Essays in Honour of John Milton (2007).
} 
Sadly, the court would seem to have focused more on reducing the harsh punishment meted out by the court a quo rather than strongly condemning the physical assault and intimate sexual violation committed against the 8 months pregnant woman. One cannot help but ask, whether a woman indeed is worth more than an item of clothing if she can be battered and sexually violated at will and her violator is undeterred simply because traditionally she is seen as a partner or as his wife and therefore his belonging.

In a similar vein, the court in Modise $v$ The State ${ }^{38}$ as per Guru J, overwhelming echoed the fact that the court must not overlook the marital status between parties suggesting therefore, that the court at all times, when presiding over marital rape-related matters must consider the fact that the parties if married should preserve the unit. This once again begs the question, whether a woman must continue to be violated indiscriminately in the name of marriage despite the evidence in casu showing that the parties commenced divorce proceedings before the rape took place.

Another opportunity to take a strong stance against intimate rape acts was missed in 2007. In $S$ v Mvamvu, ${ }^{39}$ the court missed yet another significant opportunity to strongly condemn marital rape and send a strong warning to copycat perpetrators that may want to engage in violating women or former partners by giving more weight to traditional and customary beliefs rather than imposing harsh punishment to discourage more men from raping their wives or partners in the name of lobola. ${ }^{40}$ Lessening of the perpetrator's sentence based on "compelling circumstances" is totally unacceptable given the disregard for the criminal law in the name of traditional beliefs that women remain their husband's property until the dowry/lobola is paid back by her or her family! The court seems to have disregarded the victim's human rights, including her mental health rights - the trauma, psychological and psycho-social implications that the intimate rape had on the woman seemed insignificant once it was shown that customarily, the parties were still married, and the rape occurred during that period. Although it is now immaterial whether the victim and the perpetrator were married or intimate meaning parties cannot hide behind matrimony any longer, ${ }^{41}$ sadly, the issue of marital rape lingers on. The courts' intolerance was recently demonstrated in the Jezile case ${ }^{42}$ when the court stated, "It's intolerable that very serious crimes such as trafficking, rape and assault are committed under the guise

\footnotetext{
[2007] ZANWHC 73.

2005 (1) SACR 54 (SCA).

S 1 of the Recognition of Customary Marriages Act 120 of 1998 defines lobola as "the property in cash or in kind ... which a prospective husband or the head of his family undertakes to give to the head of the prospective wife's family in consideration of a customary marriage." In effect, it may also be called the bride-price.

41 Criminal Law (Sentencing) Amendment Act 2007 provides the minimum sentencing guidelines for rape, including unsatisfactory and prohibited reasons for justifying a lesser sentence for rape. S $3(\mathrm{aA})$ states that "When imposing a sentence in respect of the offence of rape the following shall not constitute substantial and compelling circumstances justifying the imposition of a lesser sentence: (i) The complainants previous sexual history: (ii) an apparent lack of physical injury to the complainant (iii) an accused person's cultural or religious beliefs about rape or (iv) any relationship between the accused person and the complainant prior to the offence being committed."

422015 (2) SACR (WCC); 2016 (2) 62.
} 
of culture, tradition, and religion. Both parties to any marriage must consent thereto. Hiding behind now defunct customs to satisfy one's own needs must be discouraged". The case, however, echoes that gender-based violence, including sexual violence in a marriage cannot be justified in the name of culture. Although the court did not specifically deal with the issue of "marital rape", the problem was incidental to the actual abduction of the young victim for marriage purposes, which later showed how she was raped by the socalled traditional spouse through the ukuthwala process. ${ }^{43}$

\section{The role of the Sexual Offences Court (SOC) in addressing rape crimes}

As the name of the court implies the SOC deals specifically with sexual offences and consists of specialised prosecutors, social workers, investigating officers, magistrates and health professionals. The SOC was initiated by the Attorney-General of the Western Cape at the Wynberg Regional Court, in Cape Town, in $1993 .{ }^{44}$ It was created to:

"reduce the insensitive treatment of victims in the criminal justice system by following a victim-centred approach; to adopt a coordinated and integrated approach among the various role-players who deal with sexual offences; and to improve the investigation and prosecution, as well as the reporting and conviction rates in sexual offences cases".

According to Kruger and Reyneke, the SOC was different from general regional courts; because a victim-centred approach was followed even before the trial commenced; once a report is made to the police, a multidisciplinary team rendered services to the victim; and a social worker from the then Department of Welfare was appointed as a full-time, victimsupport services coordinator, who arranged for intermediaries and appropriate services and the counselling of victims. ${ }^{46}$ Though the SOC was located in the Magistrate Court building, it was located on a separate floor to prevent face-to-face contact of the accused person with the general public or the victims who waited to testify; two prosecutors were also allocated to each case for better efficiency. ${ }^{47}$ Other facilities at the Wynberg Court include private waiting rooms for victims and a closed-circuit television (CCTV) which enabled victims to testify in a separate room, while the court officials were monitored in the courtroom via a television monitor. ${ }^{48}$ The SOC was evaluated in 1997 and was found to be "partially successful in establishing integration and teamwork among different role-players dealing with sexual offences, in reducing victim trauma and in improving reporting

43 Ukuthwala is a preliminary procedure to a customary marriage whereby a woman is abducted by her suitor to commence the marriage process.

44 Department of Justice and Constitutional Development "Report on the Re-establishment of Sexual Offences Courts" August 2013 http://www.justice.gov.za/reportfiles/other/2013-sxocourts-report-aug2013.pdf (accessed 2016-02-26) 17.

45 Ibid.

46 Kruger and Reyneke "Sexual Offences Courts in South Africa: Quo Vadis?" 200833 Journal for Juridical Science 3238.

47 Ibid.

48 Kruger and Reyneke 200833 Journal for Juridical Science 39. 
and conviction rates." ${ }^{49}$ It was also suggested that there should be continuous specialised training for all court personnel, to improve the prosecution and adjudication of sexual offence cases, and the provision of district surgeons to be available on a 24-hour basis to avoid delays in forensic examinations. ${ }^{50}$ The National Prosecuting Authority ${ }^{51}$ thereafter established the National Sexual Offences Court Task Team in 1998, to facilitate the creation of SOCs in all regional court districts in the country. The Sexual Offences and Community Affairs ${ }^{52}$ Unit developed a Blueprint for Sexual Offences Courts in 2002 after it identified the lack of official guidelines to run the SOC as one of the shortcomings of the Wynberg Court Model. The blueprint requirements include "special courts with appropriate facilities, 2 prosecutors per court, experienced magistrates, victim assistant services, counselling services, administrative support, case managers, intermediaries and legal aid attorneys". ${ }^{53}$ Through the SOC, there was "an increase in conviction rates and a decrease in turnaround time from the date of the report to the police to the finalisation of the case". ${ }^{54}$ However, due to the inadequate personnel, and unavailability of facilities and equipment to follow the blueprint stipulated by the SOCA Unit, the SOCs operated more like regular courts, and soon became regular courts where other matters unrelated to sexual offences were heard.

In 2013, the Department of Justice and Constitutional Development committed itself to the establishment of 57 sexual offences courts throughout South Africa. ${ }^{56}$ On 23 August 2013, the first sexual offences court was opened in Butterworth in the Eastern Cape. ${ }^{57}$

\section{Has South Africa done enough?}

The existence of radical or progressive laws in a country does not expressly eliminate every act of rape, particularly, marital rape. Despite South Africa's laws being a progressive one, marital rape, which undoubtedly constitutes a gross violation of women's integrity and dignity, remains problematic. Although, there are poor statistics on the extent of this crime, in 2009, the South African Medical Research Council in its report indicated, "14.3 percent of men had disclosed the rape of a current or ex-girlfriend". Similarly, in its 2010 report, the Medical Research Council showed that "18.8 percent of women admitted during interviews that they were subjected to marital/partner rape on one or more occasion, with a similar figure of 18.2

49 Department of Justice and Constitutional Development http://www.justice.gov.za/reportfiles/ other/2013-sxo-courts-report-aug2013.pdf 18.

50 Ibid.

51 Hereinafter "the NPA".

52 Hereinafter "SOCA".

53 Kruger and Reyneke 200833 Journal for Juridical Science 43.

54 Department of Justice and Constitutional Development http://www.justice.gov.za/reportfiles/ other/2013-sxo-courts-report-aug2013.pdf 23.

55 Department of Justice and Constitutional Development http://www.justice.gov.za/reportfiles/ other/2013-sxo-courts-report-aug2013.pdf 24-25.

56 Manyathi-Jele "Justice Department on Target with Establishment of Sexual Offences Courts" undated http://www.derebus.org.za/justice-department-target-establishment-sexualoffences-courts/ (accessed 2016-02-26).

57 Ibid. 
percent of men admitting to forcing their current or ex-partners or wives to have sex when they did not want to" ${ }^{58}$ This high prevalence may be attributed to better under-reporting of the crime, given that many women would rather live with the shame or embarrassment rather than admit to being raped by a partner or an ex-boyfriend. In the absence of accurate data on the problem, we may never understand the depth of the marital rape problem in the country, nevertheless, every form of rape is dehumanising, traumatic and therefore amounts to gender-based violence against women and must be condemned in the strongest possible manner. ${ }^{59}$

In an effort to curb the problem of marital rape, it would seem like more work is to be done by sensitising members of society about the problem and its implications for the victims who may suffer irreparable psychological and psycho-social mental health problems as a result of the violence. Further, the role of traditional leaders in rural areas, positive male role models cannot be overstated in ameliorating or eradicating the problem. Discriminatory cultural and customary practices fuelling marital rape must be abrogated totally with the criminal justice system condemning every form of genderbased violence in its entirety. Also, the role of the media houses giving accurate and reliable news on the subject matter may help to unveil hidden and unreported sexual attacks, ${ }^{60}$ the media should, therefore, be more sympathetic to victims rather than judgmental. Further, the police and related office, should respond more swiftly to victims when reporting and make the environment less hostile to encourage disclosure or cooperation, police officers may need to embark on additional training in order to effectively carry out this function. The police can also work closely with nongovernmental organisations that render counselling assistance so victims can get professional help where needed.

\section{$4 \quad$ NIGERIA}

\section{Criminal Code Act and Penal Code Act}

Before discussing the laws, it is essential to note that the National Assembly of Nigeria makes laws for the entire Federation on matters in the Exclusive List in the Constitution of the Federal Republic of Nigeria, 1999, ${ }^{61}$ while the Houses of Assembly of each state make laws on matters in the Concurrent List. With regard to Criminal Law, the Penal Code Act, ${ }^{62}$ which is based on Sharia Law, operates in the North, while the Criminal Code $\mathrm{Act}^{63}$ operates in

58 Gender Links and the Medical Research Council "The War at Home - Preliminary Findings of the Gauteng Gender Violence Prevalence Study" 2010 mrc.ac.za (accessed 2016-0314).

59 Committee on the Elimination of Discrimination against Women, Summary Record of the 390th Meeting - Consideration of Reports Submitted by South Africa, 2002 par 9.

60 Vetten "Rape stats poorly reflect reality" 22 June 2015 https://www.wits.ac.za/news/latestnews/general-news/2015/2015-06/rape-stats-poorly-reflect-reality.html (accessed 2017-0707).

61 Hereinafter "the 1999 Constitution".

62 Cap 3-1, Laws of the Federation of Nigeria, 2004. Hereinafter "the Penal Code".

63 Cap C38, Laws of the Federation of Nigeria, 2004. Hereinafter "the Criminal Code". 
the South and the other parts of the country. Section 357 of the Criminal Code provides that:

"any person who has unlawful carnal knowledge of a woman or girl, without her consent, or with her consent, if the consent is obtained by force or by means of threats or intimidation of any kind, or by fear of harm, or by means of false and fraudulent representation as to the nature of the act, or in the case of a married woman, by personating her husband, is guilty of an offence which is called rape".

Section 6 of the Criminal Code has defined unlawful carnal knowledge to mean "carnal connection which takes place otherwise than between husband and wife". Ekhator posits that the basis for this law can be traced to the cultural and religious antecedents of the Nigerian society. ${ }^{64}$ It has been argued that a man may be found guilty of raping his wife if the marriage has been dissolved or if a competent court has made a separation order containing a clause that the wife is no longer bound to cohabit with the husband.

According to section 282(1) of the Penal Code, a man is said to commit rape when he has sexual intercourse with a woman against her will; without her consent; with her consent when her consent has been obtained by putting her in fear of death or hurt, ${ }^{66}$ with her consent when the man knows that he is not her husband and that her consent is given because she believes him to be her husband; or with or without her consent, when she is under fourteen (14) years of age or of unsound mind. Section 282(2) provides that sexual intercourse by a man with his wife is not rape if she has attained puberty. ${ }^{67}$ This is also accentuated with the provision on wife battery in the Penal Code. Section 55(1)(d) provides that nothing is an offence, which does not amount to the infliction of grievous hurt by a husband for the purpose of correcting his wife, such husband and wife being subject to any customary law in which the correction is recognised as lawful. This implies that a husband is allowed to "hit" his wife for the purpose of "correcting" her, provided he does not inflict grievous hurt on her.

It can be inferred from the combined reading of sections 6 and 357 of the Criminal Code and section 282 of the Penal Code that in Nigeria, unwanted sexual intercourse between a husband and wife cannot be termed unlawful. In addition, by reading the sections, it is clear that rape is only committed upon penetration of the female genitalia by the male penis. ${ }^{68}$ This is unlike the law in other jurisdictions, particularly in South Africa, which recognises the use of other body parts or objects to penetrate the genitalia, mouth, or anus.

64 Ekhator "Women and the Law in Nigeria; A Reappraisal" 201516 Journal of International Women's Studies 285288.

65 Okonkwo and Naish Criminal Law in Nigeria 2ed (2008) 272.

66 Eg, duress.

67 Puberty is defined as the age at which a young person is physically capable of sexual reproduction, mostly between the ages of 9 and 13 for girls. See Matlin The Psychology of Women 7ed (2012) 109-110.

68 Obidimma and Obidimma "Spousal Rape in Nigeria: An Aberration" 201513 International Journal of African and Asian Studies 172174. 


\section{Law Reform and Marital Rape under the Nigerian Criminal Law}

The problem of marital rape or rape in general is evident and remains underreported in Nigeria. There is limited media coverage on the issue of marital and research carried out on the topic is very scanty with little or no statistics on the problem of marital rape throughout the country. Further, victims are sometimes too scared or ashamed to talk about their ordeal or accept the fact that they were raped by their partner or spouse. Perpetrators, therefore often go unpunished and even when caught, the punishment meted out by the courts is often directed at rape generally and the issue of "marital rape" is downplayed - many still believe that a man cannot be accused of raping his own wife. Advocacy groups argue that it is difficult to secure a conviction generally in rape, including marital rape-related cases since the evidence of the victim must be corroborated by other testimony that is not always easy to obtain. ${ }^{69}$ Over the years, the Nigerian courts have taken differing stances on the issue. In Ogunbayo $v$ The State ${ }^{70}$ the appellant who was charged and convicted of raping a thirteen (13) year-old girl ${ }^{11}$ challenged his conviction in the Supreme Court hoping to show that the rape victim's case was improperly corroborated in the lower court. On Appeal to the Supreme Court, the Court defined corroboration as "evidence tending to confirm, support and strengthen, other evidence sought to be corroborated." The court made reference to the case of Reekie $v$ The Queen, ${ }^{72}$ where it was stated as follows:

"In the cases of a sexual character, it is eminently desirable that the evidence of the complainant should be strengthened by other evidence implicating the accused person in some material particular. It is true that there is nothing in law to prevent the Court from convicting on the corroborated evidence of the complainant, but it is an established rule that the presiding Judge must direct himself and the assessors in such a case on the desirability of there being corroboration of the complainant's evidence."

In his concurrent judgment, Niki Tobi JSC stated that:

"there are two dimensions to the issue of corroboration as decided by the courts. First, the courts hold that rape is not an offence in which corroboration is required by law and procedure. But, the court should warn itself of the danger of convicting an accused on rape charges in uncorroborated evidence. Second, an accused person cannot be convicted unless the evidence of the "prosecutrix" is corroborated."

Niki Tobi JSC, however, identified the difficulty in securing corroboration for rape cases, including marital rape because the offence is usually committed in private and the prosecutrix may not want to attract the public or

69 Olatunji "Penetration, Corroboration and Non-consent: Examining the Nigerian Law of Rape and Addressing its Shortcomings" 20128 University of Ilorin Law Journal (UILJ) 7991.

70 (2007) 8 NWLR (Pt. 1035) 157.

71 Hereinafter "the prosecutrix".

2 (1954) 14 WACA 501.

33 Niki Tobi JSC supported this assertion by referring to the decision of the court in The State $v$ Ogwudiegwe (1968) NMLR 117 for the first dimension and Akpanefe $v$ The State supra, Sambo $v$ The State supra for the second dimension. 
condemnation by announcing the rape act. The Court found that the evidence of the prosecutrix's father was sufficient corroboration - without the evidence of the medical doctor.

Although it may be inferred from the above that there is no specific law stating that there must be corroboration of the evidence of a prosecutrix to convict an accused person of the offence of rape that does not mean corroboration will not be necessary for conviction. ${ }^{74}$ Olatunji argues that where an accused person is convicted on the uncorroborated testimony of a victim, such conviction may be quashed on appeal on the basis of technicalities. ${ }^{75}$ The court thereafter found that the evidence of the prosecutrix was adequately corroborated by her father and the medical doctor who examined her after the incident. In all, the court dismissed the appeal and upheld the decision of the trial court and Court of Appeal.

It is worth noting that much emphasis was placed on the evidence of the medical doctor who examined the girl. The question, which this case brings to mind, is what happens to a rape victim who does not go to the hospital immediately after the incident - due to the trauma experienced and fear of being ostracised or disbelieved. In addition, the medical doctor, in his evidence, stated that the lacerations observed in the vagina of the prosecutrix could have been caused by the insertion of any object. This emphasises another issue in the Criminal Code with respect to the lack of recognition of other objects into the vagina of a victim. ${ }^{76}$

On the ingredients for the offence of rape, the court stated that the essential ingredient for the offence of rape is penetration, and sexual interference is deemed complete upon proof of penetration of the penis into the vagina. Thus, as stated earlier, insertion of objects into the genitalia does not amount to rape.

In Posu and Anor $v$ The State ${ }^{77}$ the appellants were arraigned before the trial court on a two-count charge of conspiracy to commit rape and rape. The appellants were convicted and sentenced to one year and three years of imprisonment respectively, for conspiracy to commit rape and rape. Being dissatisfied with the decision of the trial court and the Court of Appeal, they appealed to the Supreme Court. The court made reference to Ogunbayo $v$ The State and held that the most important ingredient of the offence of rape is penetration. However, what happens in situations of attempted rape? The evidence of the person who witnessed the incident and the medical practitioner who examined the prosecutrix was sufficient to convict the appellants. In his concurrent judgment, Adekeye JSC highlighted the ingredients the prosecution must prove on a charge of rape, as follows:

74 See Nwazuoke "A Critical Appraisal of the Violence Against Persons (Prohibition) Act, 2015" 201647 Journal of Law, Policy and Globalization 69 70, where the author stated that corroboration, though not a requirement of law, is a rule of practice which is usually needed to secure the conviction in rape cases.

75 Olatunji 20128 University of Ilorin Law Journal 91.

76 A distinction may be drawn between the Nigerian Criminal Code and the Criminal Law (Sexual Offences and Other Related Matters Act) of South Africa. While the former does not recognise the insertion of other objects apart from the penis into the vagina as rape, s 1 of the latter has a wider definition of rape to include insertion of any body part or object into the genitalia, anus or mouth of the victim.

77 (2011) 2 NWLR (Pt. 988) 382. 
"(a) That the accused had sexual intercourse with the prosecutrix.

(b) That the act of sexual intercourse was done without her consent or that the consent was obtained by fraud, force, threat, intimidation, deceit or impersonation.

(c) That the prosecutrix was not the wife of the accused.

(d) That the accused had the mens rea, the intention to have sexual intercourse with the prosecutrix without her consent or that the accused acted recklessly not caring whether the prosecutrix consented or not.

(e) That there was penetration."

On the issue of corroboration, he stated as follows:

"Evidence of corroboration of the evidence of the victim in a rape case is not required as a matter of law; it is now a well-established practice in the courts in Nigeria. The nature of the corroboration must depend on the peculiar facts of each case. Where rape is denied by the accused, the evidence of corroboration that the court must look for is for instance -

(a) Medical evidence showing injury to the private part or to other parts of her body which may have been occasioned in a struggle,

(b) Semen stains on her clothes or the clothes of the accused or on the place where the offence is alleged to have been committed."

The above buttresses the fact that corroboration, though difficult to obtain in certain instances, is necessary to secure the conviction in rape cases.

\section{Is Nigeria doing enough?}

By virtue of Section 358 of the Criminal Code, any person who commits the offence of rape is liable to imprisonment for life - with or without whipping. Adekeye JSC, while commenting on the propriety of the sentence imposed in Posu and Anor $v$ The State, stated, "the offence of rape is by every standard a grave offence which often leaves the victim traumatised and dehumanised. A light sentence as in the case of the appellants must never be imposed. This may have the unsavoury effect of turning rape into a pasttime by our flippant youths." Rhodes-Vivour JSC, in the same case, also stated that since the respondents did not feel there is a need for a crossappeal to challenge the sentence, nothing could be done to review the sentence.

Over the years, the judiciary has attempted to increase the sentence imposed on accused persons found guilty of rape. In Musa $v$ The State ${ }^{78}$ the appellant was charged with the rape of a five-year-old girl in Kano State (Northern Nigeria). The trial court, after considering the evidence before it, convicted the appellant and sentenced him to 14 years of imprisonment. Being dissatisfied with the decision of both the trial court and the court of appeal, he appealed to the Supreme Court. The court cited the case of Posu and Anor $v$ The State ${ }^{79}$ with regard to the ingredients of the offence of rape and rightly affirmed the decision of both the trial court and the court of appeal. In a concurring judgment, Fabiyi JSC stated that the sentence

(2013) All FWLR (Pt. 692) 1688.

79 See fn 77 above. 
imposed by the trial court "will serve as deterrence to other aspiring rapists in the appellant's vicinity".

However, the court seemed to digress from this stance in Popoola $v$ The State, ${ }^{80}$ where the appellant was charged with the rape of a secondary school (high school) girl. At the end of the trial, the trial Judge sentenced him to five years of imprisonment with hard labour. Being dissatisfied with the decision of the trial court and the court of appeal, he appealed to the Supreme Court. The Supreme Court upheld the decision of the trial court and the court of appeal but expressed displeasure at the lenient sentence imposed by the trial court. Ngwuta JSC in his concurrent judgment noted, "the severity of punishment for rape, with particular reference to statutory variety, should rank next to capital punishment".

From the above cases, it is clear that the Nigerian judiciary takes rape cases seriously. No doubt, certain married women also go through the ordeal of rape but unfortunately, the law does not recognise marital rape. Obidimma and Obidimma, argue that victims of marital rape may hesitate to report for some reasons, including lack of a cause of action, since it is not a recognised crime in Nigeria, inability to leave the relationship, and fear of the perpetrator's revenge, among others. ${ }^{81}$ According to Bunting, the Nigerian Penal Code, through the marital rape exemption, "exonerates rapists and use the institution of marriage to legitimise violence against women, in particular, young women, who are objects of sexual violence". ${ }^{82}$ There is, therefore, the need to criminalise marital rape.

Both the Criminal Code and the Penal Code prescribe life imprisonment as punishment for perpetrators. To prove the offence of rape under the Penal Code, Ekhator explains, "a confession of four witnesses is essential otherwise, the victim could be liable for defamation where a confession cannot be procured from the offender" ${ }^{83} \mathrm{He}$ explains further that where the required number of witnesses is absent, the victim could also be prosecuted for the offence of rape. ${ }^{84}$ In this regard, married offenders are liable to be stoned to death when found guilty, while unmarried offenders are liable to a term of imprisonment of one year and caning with lashes up to a maximum of one hundred. ${ }^{85}$ This implies that where a victim who is subject to the Penal Code takes the bold step of lodging criminal complaints against her husband for rape, it is highly probable that she may be stoned to death. This position may also discourage married women from reporting rape or marital when violated. This is clearly a gross violation of the fundamental rights enshrined in Chapter IV of the Constitution of the Federal Republic of Nigeria, 1999 - particularly the right to life, the right to dignity, the right to freedom from discrimination, among others. Judging from the legal responses to the problem of marital rape or rape generally in the country, it is obvious that more must be done to eradicate the problem.

\footnotetext{
(2014) All FWLR (Pt. 715) 200.

Obidimma and Obidimma 201513 International Journal of African and Asian Studies 173.

82 Bunting "Child Marriage" in Askin and Koenig (eds) 2 Women and International Human Rights Law (2000) 682.

83 Ekhator 201516 Journal of International Women's Studies 288.
}

84 lbid.

85 Ibid. 


\section{$5 \quad$ CONCLUSION}

The effort to eradicate marital rape and every form of violence against women is a collective battle. The problem as discussed transcends boundaries and affects women all over the world. It is therefore important for countries such as South Africa and Nigeria to continue wrestling the ill relentlessly by not only transforming the laws but also embracing human rights and equity for all, regardless of gender or marital status, most importantly, the promotion of women's rights in each country. Both countries are democratic, resourceful, and progressive enough in their own way to address the problem and eliminate every form of violence against women in both South Africa and Nigeria. Certainly, laws are insufficient to eliminate marital rape activities and restore a victim's dignity or integrity, however, adequate implementation of laws and policies prohibiting marital rape will help where it can. Factors such as social change, sensitisation, advocacy programmes, non-discrimination, and equality will equally assist with protecting women better. The roles played by the courts in curtailing the problem must be highlighted, because the final outcome of a case will either deter the perpetrator or encourage copycats to follow suit.

It is worth noting that the role of cultural, religious, and traditional leaders in ameliorating the problem is equally crucial since marital rape is embedded in custom and traditional belief to an extent. To achieve uniform transformation, the problem of marital rape cannot be addressed in isolation, countries such as Nigeria and South Africa must collectively work towards eradicating gender-based violence in its totality and keep women safe from being violated even in private. By so doing, the two countries will rid their societies of criminals hiding behind the facade of culture and improve the lives of married women in their marriages or relationships. 